\title{
PHILOSOPHY AND INSPIRATION:
}

\section{CHALIER'S LEVINAS}

Emmanuel Levinas has been the lasting inspiration of the work of the French philosopher Catherine Chalier. Nearly all of her publications intersect with his though to some extent. Chalier obtained her "agrégation" in philosophy in 1971, and ten years later completed her Doctorat d'Etat ${ }^{1}$. Since 1982, she has published 9 books on Judaic and Levinasian themes, collaborated on 6 collective works, and published some 30 articles.

The themes of her works are broadly reflected in their titles: for example, Sagesse des sens: Le regard et l'écoute dans la tradition $h e b r a i q u e^{2}$. As the theme is developed, one begins to sense the infinitely more, the "world within a grain of sand." In L'Alliance avec la nature, which opens with a "commonplace," the alienation of Jews ("qui n'avaient plus que l'etude pour demeure") from nature and their orientation toward the Book, an antithesis quickly nuances that not unfounded thesis. Some of the Jewish holidays that were originally tied to the seasons began to be associated more strongly with historical events. The absolutely fundamental nature of the inquiry soon emerges: the enigma of the mixture of immanence and transcendence. Through a careful consideration of the meaning of the mitzvot, and of those biblical passages that indicate that the covenant was not only with the Jews or even mankind but with all of nature, ${ }^{4}$ it becomes apparent that it is not a question of turning away from nature in favor of the Torah, but of raising nature to the level of Torah, and of seeing the trace of the infinite in the finite.

${ }^{1}$ Catherine Chalier. Judaisme et alterite, (Lagrasse: Verdier, 1982). That same year, Verdier also republished Challier's Figures du féminin. Lecture d'Emmanuel Lévinas, which had appeared some months earlier in the series, "Questions," directed by J. Rolland, (Paris: La Nuit surveillee, 1982).

2 Catherine Chalier. Wisdom of the Senses: Looking and Listening in the Hebraic Tradition. (Paris: Albin Michel, 1995).

${ }^{3}$ Catherine Chalier. The Covenant with Nature. (Paris: Les Editions du Cerf, 1989), p. 11.

${ }^{4}$ Cf., e.g., Gen. 9:10 and Jer. 33:25. 
Since none of her works have yet found their way into English, here is my own translation of the opening paragraph of her study titled L'Histoire promise ${ }^{5}$;

L'imminence si fréquente d'une nuit interdite d'aurore menace les êtres singuliers qui, soumis aux violences de l'histoire profane ou s'efforçant d'en infléchir le cours dans un sens plus heureux, sont condamnés par elle au suspens du souffle qui anime leurs vies brèves.

How frequently the imminent threat of endless night imperils solitary souls, who, passively subjected to the violence of profane history or struggling to redirect its course in a more felicitous direction, are condemned to the suppression of the breath that sustained their brief lives. Even the most noble causes fall beneath the unjust rule that governs the course of human events. History fails to reserve their own unique places for the men and women who, together, constitute the long chain of this evolution. The very idea of such a chain, and of the precious nature of each link, brings a derisive smile to the lips of those who see in history nothing but the moments in which heroism takes precedence over the sanctity of every life, however humble. If all that counts is the relentless struggle for recognition and power, all that is worthy of the register of history are the events that lead up to its visible triumph, be it littered with broken, soon to be forgotten lives. Even the indispensable and beautiful cause of freedom and justice falls beneath the ruthless rule of history.

It is the refusal on Catherine Chalier's part to speak in a voice that would feign indifference to the human condition that is reflected in her style, and the communication of that non-indifference sets her apart as an interpreter of Levinas.

L'histoire promise does not skirt the issue of the insufficiency of explanations of history by recourse to a divine plan. It thematizes the difficulty. Although it observes that "saintliness does not need glory," we, as philosophers, are bound to try to move our understanding forward even amidst the moral scandals and intellectual impasses of our time. After Auschwitz, what theodicy?

5 The Promised History. (Paris: Les Editions du Cerf, 1992), p. 9. but since the rythmic qualities of her periodic incipit are only indistinctly reflected in English, I give as much as in the original. 
Chalier's latest book, which I have just read, is L'inspiration $d u$ philosophe: "L'amour de la sagesse" et sa source prophetique. ${ }^{6}$ The book is a carefully ordered meditation on the relation between philosophy (as we know it in the West, our philosophy that we have inherited from the Greeks, or "Athens" for short) and the Hebraic tradition of enlightenment through the hearing of a voice and the transmission of that voice through the prophets. What this amounts to is, of course, to a large extent the examination of the two sides of Levinas's work. He himself, as we know, always wanted to keep these two facets of his work separate, even using different publishers, as he points out, for the two. He never adduces scripture to make a philosophical point (or at least not in the guise of proof or substantiation of any sort). In an earlier work specifically devoted to presenting Levinas's work, titled Levinas: l'utopie de l'humain ${ }^{7}$, Chalier already explores this question in a much more succinct manner, in the her chapter "Hebrew and Greek." Her findings there are not at variance with her thesis in the work we are now considering, although the format of the earlier work restricts the elaboration and supporting arguments that could be brought forward.

Chalier takes this separation as her theme in this work, which is dedicated to the memory of Levinas, who died on December 25, 1995. Her liminary quote, "...the profound rift in a world attached at once to the philosophers and the prophets," is from Levinas's book, Totality and Infinity ${ }^{8}$. In that context, Levinas associates philosophy with the True, and prophecy with the Good; but he is not content to leave these two notions in a symmetric repose: philosophy/truth, prophecy/goodness. His constant thesis is that our experience of the infinite, the beyond thought or the absolutely other, is experience par excellence. This Cartesian moment of the thought of infinity "Overflows thought in a wholly different sense than does opinion," writes Levinas, insisting that there is no dogmatism here that would make the experience of the infinite antiphilosophical per se, by being an infringement on philosophy's autonomy. He calls this infinity "more objective than objectivity."

This most recent book of Chalier's challenges the refusal of inspiration by reason. Is an ontological rationality the only possible

"The Philosopher's Inspirations: "The Love of Wisdom" and its prophetic source. (Paris: Albin Michel, 1996, p. 9.

${ }^{7}$ Levinas: The Utopia of the Human. (Paris: Albin Michel, 1993), p. 24.

${ }^{8}$ Totality and Infitinity: An Essay on Exteriority, tr. by A. Lingis (Pittsburgh: Duquesne University Press, n.d. [1969]; Totalité et infini: Essai sur l'exteriorite. (The Hague: Martinus Nijhoff, 1961). 
rationality? Or can there be an inspired rationality, or a rationality of transcendence?

In translating, in the subtitle of her work, the word philosophy into its component parts at the outset, Chalier makes the point that before the unambiguous triumph of the concept, philosophy was larger. It was the search for truth, but also and perhaps as a necessary precondition, the leading of an exemplary life. One can distinguish a weak claim here, that the Greek philosophers' holistic mission was to find the best way to live our lives, and a stronger one (which appears in Pascal, but also in J. Halevi), that the heart has its reasons that reason does not understand, or that one must love in order to understand the most "elevated" matters.

One of the functions of Chalier's problematic is to bring this issue to a head -- this contrast between the neutrality and autonomy of reason, which is sometimes held to be the essence of philosophy, and the view that while reason may occupy the middle ground of philosophy, it is neither its alpha nor its omega. One can scarcely refrain from contrasting Anglo-Saxon (or analytic) and continental philosophy (but Chalier does not do so) in this perspective.

I shall make an initial hypothesis, of an historical nature, that has some bearing on this question. In the Western world at least, it seems that religion, philosophy and science emanated from a common amorphous ancestor. Pythagorism, for example, was at once a cult and a philosophy. Lucretius's De Natura Rerum, from the first century B.C.E., already claims that Epicurean atomism can free men's minds from the fears of superstition, although in fact science and philosophy were not yet distinct entities. In the Middle Ages, knowledge was seen as too limited to comprehend divine truth, and to stand in need of supplemental faith; in a countervailing Renaissance movement, knowledge (as in Francis Bacon's thought) becomes power over nature, a burgeoning technology. Philosophy, between religion and science, problematizes knowledge as epistemology.

But Athens is not Jerusalem. If the distinction between religion and philosophy is clear when we are thinking in terms of religion qua Christianity and of philosophy qua Greek, it becomes far less so if religion, as in the case of Levinas and Chalier, is Judaism. It is well known that the role of faith in Judaism is not analogous to its role in Christianity. One reason for this is because faith plays a defining role in the latter case, since to be a Christian is to believe in the divinity of Christ, while Jews may be said to be "over-determined" before the letter. 
To return now to L'Inspiration du Philosophe, Chalier points out in her preface that the goal is not to declare a victory of the philosopher over the prophet, nor vice versa. Such an enterprise, she assures us, would be "vain and violent ${ }^{9} . "$ But to consent to this tension is not an illegitimate acceptance of the irrational on the part of philosophers: it is rather "the overthrow of the idea that men, and especially institutions, have of the essence of philosophy and prophecy." She then proceeds to elucidate the major themes and movement of Levinas's philosophy. It is a movement through and beyond the dialectic of the Same, ever assimilating the Other in the guise of "grasping" or understanding, towards an asymmetrical relation in which the Other remains other, haunts, troubles, keeps wakeful and vigilant the Same, which would otherwise sink into coincidence with itself: the bad ideal of philosophy. Alteration is the other person, but also the absolute Other of God. A God not contaminated by being, beyond onto-theo-logy, otherwise than being.

Chalier defines the question her book seeks to answer in the following terms.

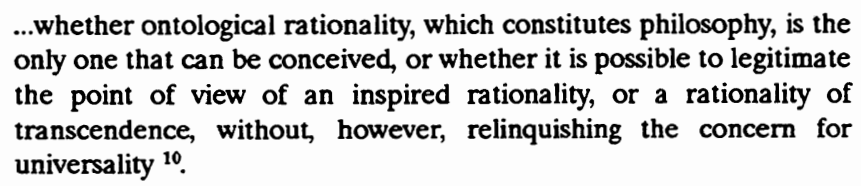

Living the tension between philosophy and prophecy is better than "a discourse of exclusion." Chalier further suggests that the desire to defend the purity of the essence of philosophy may mask a position of power. It seems clear that she is alluding to the structure of the profession of university professors of philosophy in France, though the implications are broader. Chalier distinguishes, in passing, the language of prophecy from that of poetry, while granting kinship. The Logos is not capable of knowing "individual suffering," while the prophets do not authorize such forgetfulness. Nor is the rift between philosophy and prophecy just academic: it is displayed in the history of the century, in the "ignominy that man imposes on his fellow man, in the name of barbaric causes." But cannot philosophy, without ceasing to be philosophy, bring man to an awareness of a source of meaningfulness that speaks of the promise of the advent of the human in being?

${ }^{9}$ L'inspiration du philosophe, p. 10.

${ }^{10}$ Ibid., pp.12-14. 
Chalier emphasizes the wisdom/knowledge distinction in order to reinforce the thesis of philosophy as love of wisdom, hence of a way of life, not just a conceptual endeavor. ${ }^{11}$. She applies a midrash (from the Midrash Raba) on the Tower of Babel episode (Genesis 11:4 et seq.): it is a warning not to leave the "Orient," which in Hebrew is also origin (quedem), or, according to Rabbi Eleazar bar Shimeon, to leave the Ancient One of the World (Quadmuto). Chalier moves the text in the direction of a refusal to recognize divine alterity, and subsequently any alterity. Here we have an echo of Levinas's doctrine of self as Same, and its lack of recognition of Otherness or Alterity would be the fate of a philosophical language that invents its autonomous verb, rejecting all others as non-philosophical.

Closely allied to this theme is that of the translation of the Hebrew Bible into Greek. Levinas treats this theme extensively in his Time of the Nations, in a Talmudic lesson titled: The Translation of the Scripture $^{12}$. It was necessary and good to accept the language of the Greeks -- i.e. the inspired wisdom of the Hebrews accepts the risk of being expressed in the language of philosophy -- but not their wisdom-because that wisdom does not accept the possibility that the existence of multiple interpretations could signify anything but their imperfection and remoteness from truth.

The multiplicity and irreplaceable value of interpretations (which is typical of Talmudic study) is valorized in Chalier's study, which speaks of the "nobleness of the hermeneutic task." In the tradition of Talmudic study, the consecrated phrase is: "These and those are the words of the living God." But Chalier is far from depriving the Greek Logos of its truth, in favor of the Hebrew Davar (=word and/or thing). The former, present in all its anteriority and mystery in the fragments of Heraclitus, was progressively abandoned by the philosophical tradition in the West. But although it is true that Plato exiles poets from his City, he does call upon the philosophical equivalent of Mythos, allegory, in attempting to understand the workings of love and the soul.

Chalier's next chapter, "The Saying and the Said," treats the

11 Spinoza, though underestimating the importance of scripture, does insist on philosophy's being a modification in our way of desiring and wishing, not just thinking. See Chalier's a study on Spinoza, which comprises the first half of her Pensées de l'eternite: Spinoza, Rosenzweig Editions du Cerf, 1993.

${ }^{12}$ In the Time of the Nations, tr. M.B. Smith. (Bloomington: Indiana University Press, 1994), esp. 52 ff; from $A$ l'heure des nations. (Paris: Les Editions de Minuit, 1988) esp. 63 ff. 
question of the link between reason and ontology. It opens with the Nietzschean contrast between Apollonian clarity and Dionysian emotion and disorder. This points in the direction of the verbal austerity (a severe asceticism of words) often preferred in philosophy. Some philosophers, Spinoza among them, consider that words and images stand between us and the true essence of things. Words and images are "external," and a hindrance to the ideal of transparency.

The argument proceeds, studded with quotes from Levinas, midrash and the Bible, to argue in favor of a kind of reason that would be open to "inspiration." Inspiration is understood on the analogy with breathing (the Hebrew "ruah": breath, wind or spirit). The inspiration being described is from the Other to the other, i.e. from God to us in a form that becomes as personal to us as we ourselves are unique, enabling us to pass on that inspiration, but in an inimitably personal form, to the other person.

As an eruption into Western philosophy, Levinas is quite untimely. Although he does not fail to comment on the philosophical movements by which he is surrounded, there are no deep affinities between his metaphysics and French existential phenomenology, and even less with structuralism, cultural anthropology, Lacan's neo-Freudian thought, and postmodernism. At the heart of his work we have a critique of ontology and a return to metaphysics. What Levinas gives us is a new metaphysics, based on the contrast between totality and infinity, and positing the primacy of ethics. It is cruelly ironic that the one twentiethcentury philosopher with whom Levinas's work does have connections, Martin Heidegger, became a Nazi. Levinas's work is to be situated along the line of German existential phenomenology. His early studies of Edmund Husserl and his later critique of Heidegger are the moments of his thought that engage the Western philosophical tradition most closely. That aspect of his work has been examined by Jacques Rolland, Marlene Zarader and Alain David, among others.

But that is not the approach taken by Chalier. Chalier, as I have said, places Levinas within the tradition of Jewish thought. This gives her work a coherence lacking in other approaches, because it allows her to present his work as whole, centered within itself as it were. But her approach is not regressive: she does not reduce Levinas's thought to some original elements that would be the original units, somehow, of a Levinasian synthesis. It is rather the case that Chalier, as both a European philosopher and a Jew well versed in the Judaic heritage, is able to present Levinas's thought in its simple specificity. Although her approach does not explore Levinas from the point of view of the 
phenomenological tradition in the way others attempt to do, it may itself be called phenomenological, in that it follows the Husserlian principle of respecting the specific "evidence" of its realm, viz. the thought of Levinas.

On the other hand, paradoxically, there is a sense in which the unity of Levinas's work is most evident in its dichotomy. That is what is most proper to it, and most central. Its specificity, like that of so much of European Jewry, is its cultural overlap, and the resultant inner split--as exemplified in the "gespaltete Seelen" or split souls of the sixteenthcentury marranos or conversos of Spain. I will venture to suggest that Levinas's originality is the continuation of a phenomenon mentioned by Michel de Certeau in his introduction to The Mystic Fable ${ }^{13}$ :

\begin{abstract}
Just as the massive adoption of German culture by the Jews of the nineteenth century made possible theoretic innovations and an exceptional intellectual productivity, the upsurge of mystics in the sixteenth and seventeenth centuries was often the effect of the Jewish difference in the usage of a Catholic idiom.
\end{abstract}

I do not wish to imply that Levinas is a mystic, nor that a Jewish approach to Levinas is more valid than a phenomenological one. I merely wanted to impart a sense of the relation of Chalier's work to Levinas's. Both Chalier and Levinas are "bilingual," conversant in the idioms of both Athens and Jerusalem. But just as Yiddish began as an attempt to communicate with the local inhabitants and evolved into a new particularism, so Levinas's philosophy, for all its bilingualism, ends up practicing, according to his felicitous phrase, an "indiscretion vis-à-vis of the ineffable" that contrives to suggest what neither component idiom can say severally. To the question the preceding considerations might raise, as to whether the unity of Levinas's thought is best grasped from within Judaism or from without, I would tender a Hegelian "both."

It would not be difficult to criticize Chalier's treatment of Levinas as being uncritical. And it would not be untrue to say that Chalier's works are "works of piety." But I would not want them to be different. Chalier's are among the few books of their type I tend to re-read, not because I have not understood, but because they provide a medium in which thought and sprirituality seem happy to be together. Their style gives access to a certain mental temper in which a Messianic peace

${ }^{13}$ Michel de Certeau, The Mystic Fable. tr. M.B. Smith (Chicago: Chicago University Press, 1992). p. 23. from La Fable mystiquee (Paris: Gallimard, 1982), pp. 39-40. 
seems, if not immanent, at least not impossible; a peace not to be confused, as Levinas points out and Chalier emphasizes, with the artificial peace of churches and synagogues that too often promulgate a peace that might more accurately be rendered as "Leave me in peace, all you wretched ones of the earth."

Chalier's style is more rhetorical than Levinas's. She brings out the very condensed meanings of the latter, giving them breathing space, turning them loose in a larger world so that we may see how they behave in this new space. The concatenation of conjunctions in Chalier is not as marked as in most philosophical prose, but the gait is vigorous and assured as it moves from theme to theme. Still, at times I am left wondering whether I should like her work as much as I do. Her argument in favor of philosophy's discourse being open to its other, prophecy, is perhaps more pertinent to her own work than to Levinas's. Levinas, seeing the structure of receptivity as it awaited him with all its restrictions, accepted the dichotomy of scripture and prophecy more willingly than does Chalier. The latter, thematizing this difficulty, has produced a work that may in part be a reflection of, and on, the difficulties she has encountered within a university system that has been less than welcoming to her. Hence, perhaps, her inclusive or even conciliatory discourse on inspiration and philosophy -- a balm to repair a broken world.

Though much of Chalier's work is a restatement of Levinas's philosophy, often against a background of Judaic thought, her style and emphasis are very distantly her own. Marie-Anne Lescourret, in her useful biography of Levinas, ${ }^{14}$ refers to her as "l'une de ses plus constantes et fidèles exégètes." In conversation with Levinas, I once alluded to Chalier as "un de vos disciples." He corrected me: "Non, c'est une amie." At once closer and more independent.

Berry College

MICHAEL B. SMITH

346.

${ }^{14}$ Marie-Anne Lescouret. Emmanuel Levinas (Paris: Flammariona, 1996), p. 